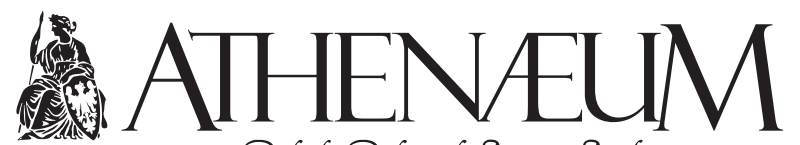

Polish Political Science Studies

Polskie Studia Politologiczne

vol. 63(3)/2019, pp. 92-116

DOI: 10.15804/athena.2019.63.07

www.athenaeum.umk.pl

ISSN 1505-2192

\title{
DO ENTREPRENEURIAL PARTIES MAKE ANY DIFFERENCE FOR POLISH POLITICS? THE CASE OF THE PALIKOT MOVEMENT AND KUKIZ'15*
}

\author{
CZY PARTIE PRZEDSIĘBIORCÓW WNIOSŁY \\ COŚ NOWEGO DO POLSKIEJ POLITYKI? \\ RUCH PALIKOTA I KUKIZ'15
}

Beata Kosowska-Gąstoł** @ Katarzyna Sobolewska-Myślik*** ๑$$
\text { - ABSTRACT }
$$

Economic crisis together with the overall crisis of liberal democracy have caused social discontent and disappointment with existing mainstream parties, which have been blamed for not being able to cope with emerging problems. At the same time new parties, which have presented themselves as an alternative, have appeared and entered parliaments. Some of them can be regarded as entrepreneurial ones. In the case of Poland this is the Palikot Movement, which managed to overcome the electoral threshold in 2011, and Kukiz'15, which did the same four years later. Both organizations have criticized the mainstream parties (especially limiting competition to $\mathrm{PO}$ and $\mathrm{PiS}$ ) and political elites and have also proposed some alternatives. The aim of the paper is to address the questions of
\end{abstract}

Kryzys gospodarczy wraz z ogólnym kryzysem liberalnej demokracji wywołały niezadowolenie społeczne i rozczarowanie istniejącymi partiami głównego nurtu, które obwinia się o to, że nie są w stanie poradzić sobie z pojawiającymi się problemami. W tym samym czasie powstały i zdołały wejść do parlamentów nowe ugrupowania, które przedstawiają się jako alternatywa wobec istniejących partii. Niektóre z nich można uznać za partie politycznych przedsiębiorców. W przypadku Polski należy wymienić Ruch Palikota, któremu udało się pokonać próg wyborczy w 2011 roku, i Kukiz'15, który zrobił to samo cztery lata później. Obie organizacje krytykowały partie głównego nurtu (zwłaszcza ograniczenie rywalizacji do PO i PiS) oraz elity polityczne, a także wysuwały alternatywne rozwiązania.

* Earlier version of the paper was presented at the ECPR General Conference, 22-25 August 2018, Hamburg.

** Jagiellonian University in Kraków, Faculty of International and Political Studies.

*** Pedagogical University in Kraków, Faculty of Political Science. 
what the "new quality" proposed within the programmes of these entities is and of whether these parties really practise what they have preached, particularly whether they use innovations related to alternative forms of democracy in their own structures and after entering parliament try to put their postulates on the state agenda.

Keywords: party programmes; Polish parties; entrepreneurial parties; new parties
Celem artykułu jest odpowiedź na pytania, na czym polega „nowa jakość" proponowana w programach tych podmiotów oraz czy głoszone przez nie postulaty są realizowane $\mathrm{w}$ praktyce, w szczególności czy wykorzystują innowacje związane $\mathrm{z}$ alternatywnymi formami demokracji we własnych strukturach oraz czy po wejściu do parlamentu starają się uczynić swoje postulaty częścią agendy państwowej.

Słowa kluczowe: programy partyjne; polskie partie; partie przedsiębiorców; nowe partie

\section{INTRODUCTION}

The subject literature has for many years produced discussion on the crisis experienced by political parties. The most frequently advanced arguments to illustrate this very crisis are the decreasing citizen participation, resulting in diminishing party membership numbers, a growing electoral volatility as well as a declining turnout (Whiteley, 2011; van Biezen, Mair, \& Poguntke, 2012; Scarrow, 2015). Another aspect of this problem has been the growing link between parties and state institutions, something that can be especially clearly seen in the cartel party model of Richard Katz and Peter Mair (1995). It is worth emphasising that these phenomena impact significantly on the way in which a party realises its functions and particularly on the function of representing interests (Enyedi, 2014, p. 194).

On the one hand, all the critical remarks made above relate to political parties as such, while on the other, it does somewhat appear that in practice they are concentrated first and foremost on mainstream parties. The consequence of such a situation is, among other things, an extremely clear tendency, one observed as equally in stabilised as in new democracies, for the creation of new groupings which in assumption may be alternative in relation to the poorly functioning "old" parties (Hartleb, 2015; Deegan-Krause \& Haughton, 2015). The expression "new groupings" is used on purpose, because apart from new political parties there is a growing activity of actors who negate the party organizational formula, but still perform functions characteristic for parties such as taking part in elections or creating governments. Good example may be the Italian Five Star Movement (Della Porta et al., 2017; Natale \& Ballatore, 2014). 
The subject of analysis are two entities on the Polish political scene, namely, the Palikot Movement (Ruch Palikota, RP), which attained enough votes to enter parliament in 2011, and Kukiz'15, which managed the same four years later. Both have been deemed by us to constitute entrepreneurial political parties (Kosowska-Gąstoł \& Sobolewska-Myślik, 2017). Their creation and activity will be examined within the context of the above mentioned phenomena connected with the deficiencies in the functioning of mainstream parties. Both analysed subjects at the moment of their inception declared their intention to create a new political quality, clearly distancing themselves from political parties hitherto functioning in Poland. It is important to add that Kukiz'15 expresses its separateness equally in its organisational formula, deciding not to adopt the form of a political party itself. Hence the article's aim is to answer the questions as to on what the new quality proposed within the programmes of these entities is based, as well as whether they manage to implement the solutions they actually propose, in particular within their own structures and parliamentary operations, and with the same whether they actually make any difference for Polish politics. The hypothesis we put here is that even if those actors strive to be perceived in Polish politics as new quality, in fact they present weak alternatives to mainstream parties both in terms of specific issues they put forward as well as organizational innovations.

The article has been divided into four parts. In the first, the Polish party system has been sketched out, showing the place taken within it by the parties under examination. The second characterises the political programmes of the Palikot Movement and the Kukiz'15 formation in relation to their criticism against mainstream parties as well as the whole politics in Poland. Presented equally are the proposed innovations and alternative solutions. The subsequent part analyses the statutes as well as the candidate selection process in order to check whether there are reflected the proposed innovations. While the final part constitutes an attempt to answer the question as to whether, following entry into parliament, the parties have tried to realise the solutions earlier postulated. This matter is analysed on the basis of parliamentary addresses made by members of both parties during Polish parliamentary sessions (at the Polish Sejm) as well as the legislative initiatives advanced by them.

The fundamental method employed in the writing of the article was a qualitative content analysis. The programmes and statutes of the parties were subject to examination as were the parliament addresses and speeches made by their members along with the legislative initiatives advanced by them. Analysed were 
the transcripts of parliamentary sessions accessed on the Polish Sejm's website (www.sejm.gov.pl). In the case of the Palikot Movement, the entirety of the $7^{\text {th }}$ parliamentary term was taken into consideration (2011-2015), while for Kukiz'15, the period from the beginning of the $8^{\text {th }}$ parliamentary term in 2015, when the organization was elected to parliament, to the end of March 2018, when research was brought to a close. Given the large number of speeches and addresses, a $10 \%$ sample of the said, randomly selected, was chosen utilising Research Randomizer for this aim (www.randomizer.org). After the data had been compiled, all the texts were analysed in relation to the appearance within them of references to key concepts and notions such as: representative democracy as well as alternative forms of democracy, rule of law (including the idea of legalism and the principle of decent legislation), elections, organs of state power, rights and the freedoms of the individual, state-church relations, political elites, bureaucracy, particracy, corruption, nepotism. The subjects present in the documents analysed were ordered into two groups: in the first were placed criticism in relation to mainstream parties and Polish politics itself, while in the second - the propositions for the changes postulated. The analyses - illustrated by quotes and their interpretation - allowed us to identify the main trends occurring within each party and to answer the research questions.

\section{ENTREPRENEURIAL POLITICAL PARTIES AND THEIR PLACE WITHIN THE POLISH PARTY SYSTEM}

The Polish party system started to stabilise midway through the first decade of the $21^{\text {st }}$ century. Following the elections of 2005 the Sejm was for the first time to be comprised of the same six political parties that had held seats during the previous parliamentary term, though there was an obvious marked shift in electoral support when compared to the year 2001 (van Kessel, 2015, p. 127). The hitherto political cleavage between post-communist parties and those representing the Solidarity movement was to be replaced by a rivalry between two political groupings from the Solidarity camp - the Law and Justice (Prawo i Sprawiedliwość, PiS), and the Civic Platform (Platforma Obywatelska, PO; Markowski, 2006). The early election of 2007 was to bring about further stabilisation in terms of both the number of parties and the types of electoral competition. Only four political groupings managed to poll enough votes to enter parliament with the main rivalry still being between PiS and PO (Markowski, 2008). The party system at the 
parliamentary level was viewed as closed to small and new parties, which were not able to compete with those political groupings who possessed sizeable budgets.

In the general election of 2011, for the first time since 2001, a new political party - the Palikot Movement - was to enter parliament (Szczerbiak, 2013, p. 480). The political grouping had come into being just before the election and had built up its political capital through attacking the elites and criticising the election competition between PO and PiS (Stanley \& Cześnik, 2016, p. 706). The Palikot Movement constituted the third largest parliamentary grouping, behind PO and PiS, but ahead of the Democratic Left Alliance (Sojusz Lewicy Demokratycznej, SLD) and the Polish Peasant Party (Polskie Stronnictwo Ludowe, PSL). In 2015, the main axis along which competition ran was again that of PO and PiS. PiS won the election and was able to form a single party government with a parliamentary majority enabling it to rule without the need to create a coalition (Markowski, 2016, p. 1311). The Palikot Movement ran within the auspices of a wider coalition, which was unable to gain sufficient votes to cross the election threshold resulting in the party finding itself outside of parliament. However, two new political formations - Kukiz'15 and the Modern Party (Nowoczesna) - were to take up parliamentary seats.

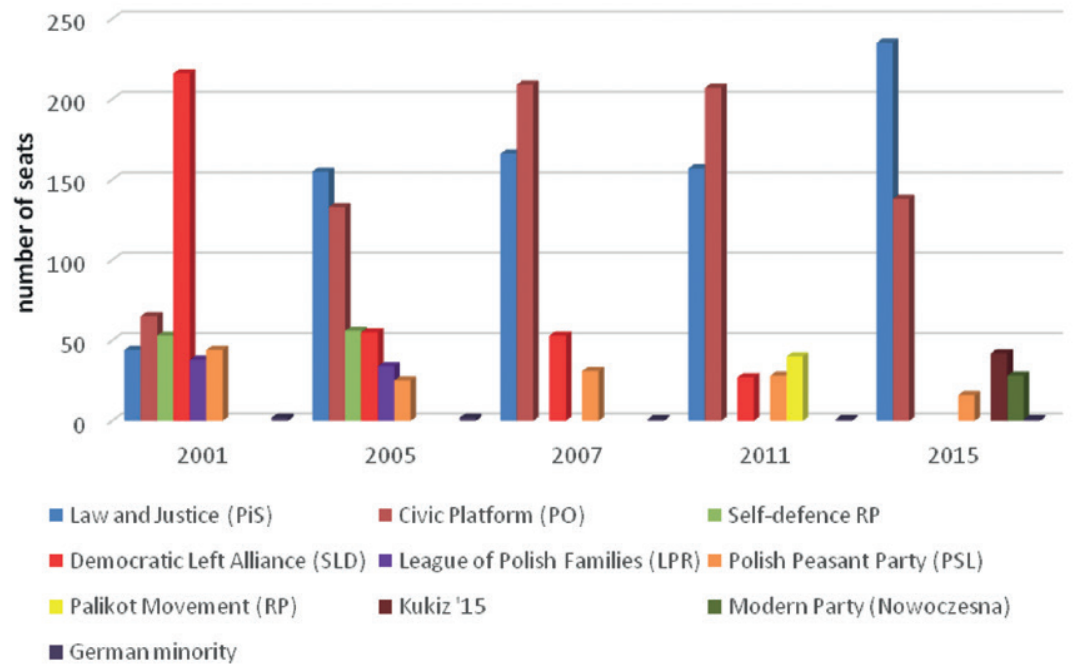

Figure 1. The Numbers of Seats Obtained by Polish Parties in Parliamentary Elections 2001-2015

Source: developed by the authors based on www.pkw.pl. 
The common feature of all the new groupings that managed to enter parliament in 2011 (the Palikot Movement) and 2015 (Kukiz'15, Nowoczesna) is that they came into being only a short time before the election and quickly were able to gain electoral support. Besides, they were formed by more or less charismatic leaders, who, on the one hand, represented the crux of the formations' electoral appeal while on the other, treated their parties as a "personal vehicle" (Lucardie, 2000) to achieve their own political goals (Hopkin \& Paolucci, 1999; Krouwel, 2006). Equally in common was the fact that these groupings arose from nothing, for they are not party splinters as well as not basing themselves on social movements or sponsoring organisations, which would have provided them with resources and electoral support. All of this meant that in the research conducted in 2016 (Kosowska-Gąstoł \& Sobolewska-Myślik, 2017), the aforementioned parties were deemed to fulfil the criteria for the minimal conceptualisation of entrepreneurial parties as defined by Hloušek and Kopeček (2017). Ryszard Petru's political party Nowoczesna was also considered to be an entrepreneurial party in the work cited, yet this has been omitted from the study as a result of the changes occurring within it; changes that simply did not allow for its continued inclusion within the category of entrepreneurial parties. Hence only the Palikot Movement and Kukiz'15 are the subject of analysis for the sake of this article.

The Palikot Movement was formed by the businessman Janusz Palikot, who had begun his political activities in 2005 while a parliamentary deputy for PO. In 2010 he left the party, creating the Palikot Support Movement, and subsequently the Palikot Movement, which since 2013 has borne the name Your Move(ment) - Twój Ruch, TR 1 . The party's founder was, on entering politics, one of the richest men in Poland, hence he announced that the aim set for his activities was not enrichment but a fixing of the state. While a deputy for PO he had headed the "Friendly state" parliamentary commission, in which he strove to implement changes aimed at reducing bureaucracy and building up trust between the state and citizens. He was better remembered for his press conferences during which - utilising controversial props such as a toy pistol, vibrator, a pig's snout - he attempted to draw attention to the problems of the day. However, the approach adopted was to turn out to be inappropriate, as was borne out by the defeats in the European Parliament and local government elections of 2014 and the

1 In the current article these names will be used interchangeably. The Polish word "ruch" means both 'move' and 'movement', hence the party name can be translated differently, both Your Move and Your Movement. 
presidential and parliamentary elections that took place in 2015 (KosowskaGąstoł, 2018).

Kukiz'15 is formally known as the Association for a New Constitution Kukiz'15 (Stowarzyszenie na rzecz Nowej Konstytucji Kukiz'15), which came into being four months before the parliamentary election of 2015. The association formula was deliberately adopted as this differentiated the formation from political parties as such. The creation of the association and its participation in the parliamentary election was inspired by the electoral success enjoyed by Pawel Kukiz in the presidential election of May 2015, in which he took third place. Paweł Kukiz's career is fundamentally connected with rock music. He started his political activity in 2007 with involvement in support for electoral reform and the creation of single-member constituencies. Initially, he engaged in the action taken by PO, only later to take up independent political initiatives: the aim of which has remained chiefly campaigning for single-member electoral districts, as well as a protest campaign against the political establishment and mainstream political parties (Kosowska-Gąstoł \& Sobolewska-Myślik, 2017).

\section{WHAT DOES NOT WORK AND HOW TO FIX IT? A DIAGNOSIS ON THE BASIS OF THE POLITICAL PROGRAMMES OF ENTREPRENEURIAL PARTIES}

The Palikot Movement and Kukiz'15 are markedly different from each other. While the former makes recourse to leftist-liberal values, the latter combines conservative principles in social behaviour with economic nationalism (Markowski, 2016, p. 1316). For both groupings, however, common is the fact that their electoral appeal is based on criticism of establishment political parties and their presentation as new political forces dissatisfied with the current situation of the Polish state as well as with the political elites in power since 1989; and as movements intent on carrying out qualitative changes within Polish politics. This was not, however, to mean the dismantling of liberal democracy based on the principle of representation but rather its reform.

The analysis of the programmes of the Palikot Movement and Kukiz'15 was to show the deficiencies reviled by them and the social pathology inherent within Polish political life as well as the changes they propose to rectify the situation. Janusz Palikot's proposals are based on the party programme comprising three parts: A Modern State. A Secular State, A Friendly State (RP/TR, 2011), the par- 
liamentary election programme of $2011(R P-2011,2013)$, as well as the draft A Plan for Changes 2014-2019 (TR, 2014). Given that the Kukiz'15 association has been in existence for a much shorter period of time what it offers as a political programme is more modest, hence the analysis is based on the programme adopted in 2015: A Strategy for Changes. You Can Do It, Poland! Kukiz'15 (Kukiz, 2015).

\subsection{Criticism of the existing regime}

In both groupings the fundamental issues deemed to take on the magnitude of problems are: the incompetency of political elites and mainstream parties, as well as particracy. The Palikot Movement disapprovingly relates to the narrowing in the electoral alternative between PO and PiS. It draws attention to the fact that the existing institutional solutions hamper the entrance onto the political scene of new parties, meaning that existing political groupings and their elites do not have to take public opinion into consideration. The parties are accused of having no political programmes, a will for change and new people. They are defined as "the leaders' private retirement funds", while the whole party system as "sick and non-democratic" ( $R P-2011,2013$, pp. 338-339). In the case of Kukiz'15, the negative attitude towards political parties is already expressed within the organisation's name, and formal status of an association announcing that "For twenty five years politicians of all parties have consistently destroyed our national community $[\ldots]$. The parties con the people". The parliamentary electoral system is also a brunt for criticism, one favouring the election of representatives connected with parties rather than with voters. As a consequence: "[...] deputies are not the representatives of the people but merely the stooges of their party leader" (Kukiz, 2015). The examples given do not exhaust the criticism of political parties. This motif constantly returns, for Your Move(ment) and Kukiz' 15 are prone to blame the establishment parties for various unsolved problems and the pathologies of political life.

An important element within this criticism is the state's inappropriate functioning and the consequent lack of trust on the part of citizens. The state is viewed as an extremely repressive institution in its dealings with citizens, not the one serving them. In the programme this is clearly connected with the lack of citizen control over particular institutions and spheres of activity. The state is criticised for, among other things, a lack of transparency in public finance and decision-making processes, something that is linked to the waste of public 
monies and corruption; the growing national debt; an overly complicated and unfavourable taxation system for citizens; and an excessive growth in public administration. Despite the fact that the formations in question differ on socioeconomic matters, both perceive and stigmatise the privileges enjoyed by huge corporations transferring profits abroad at the cost of small and medium-sized businesses, whose interests are not properly taken into consideration by Polish competition law. As far as Your Move(ment) sets out to relatively equal up the chances of Polish business and huge corporations, Kukiz'15 goes further in its criticism. It raises the issue of the excessive role played by foreign firms and investment as well as the preference given to the interests of banks over those of ordinary citizens. This picture of Poland's excessive dependence on the international community is presented not only in the context of economic policy but also finds reflection in the criticism of the Euro as a currency and the climate packet which does not allow Poland to implement an independent energy policy (Kukiz, 2015, pp. 17, 28, 30).

Both parties criticise the way the court system and the police operate. The Your Move(ment) programme shows the low level of trust amongst ordinary citizens in the justice system resulting from a conviction in the existence of "local cliques" that incorporate public prosecutors and judges (RP/TR, 2011). In turn, Kukiz' 15 criticises the lengthiness of court cases and the inappropriate practical preparation of judges, yet sees the greatest problem being "the absence of citizen control over the judiciary" (Kukiz, 2015, p. 8). Your Move(ment) is critical of the functioning of the police, who "[in] a democracy [...] should be the spokesman of the ordinary citizen over being an instrument for the defence of the authorities and the state apparatus" (RP/TR, 2011).

Your Move(ment) enumerates amongst the irregularities in the functioning of the current political system the ailing legislative process as well as excessive bureaucracy; Kukiz'15 draws attention to corruption and nepotism. The legislative process is criticised for being too lengthy, this resulting from the bicameral parliament, an absence of planning for legislative work, the passing of acts in response to current happenings, and using formal devices that allow to avoid any public consultations (RP/TR, 2011). An answer to the question of bureaucracy, criticised within Your Move(ment) programme, is the creation of new institutions in response to the appearance of some challenge or other, rather than attempting to deal with the issue through existing structures (RP/TR, 2011). Equally, in the opinion of Kukiz'15, we are dealing with an excessive increase in administrative positions, an overcomplication in the working of institutions 
and a distancing of these from the ordinary citizen (Kukiz, 2015, p. 22). In the association's programme, the problems mentioned are most often connected with a criticism of establishment parties accused of creating the social pathology now in existence. According to the Kukiz'15 association: “The level of nepotism and corruption in state and local government administration long ago exceeded any bounds of social tolerance" (Kukiz, 2015, p. 23).

The Your Move(ment) programme also contains criticism absent from the Kukiz'15 programme, this being of the relations between the Polish state and the Roman Catholic Church. The party, in emphasising that it is not hostile to the Church itself, fights with the privileged position the Catholic Church enjoys in public life. The subject of the criticism is the funding of the Church from the state budget, the teaching of the Catholic faith in state schools, as well as the presence of the Catholic clergy during state ceremonies and the display of Catholic religious symbolism in public buildings and institutions (RP/TR, 2011).

Table 1. Main Directions of the Criticism Towards the Existing Regime

\begin{tabular}{|l|l|}
\hline $\begin{array}{l}\text { political elites and } \\
\text { parties }\end{array}$ & $\begin{array}{l}\text { - particracy } \\
\text { - narrowing the electoral competition to PO and PiS } \\
\text { - the parties have no political programmes, new people and a will for change }\end{array}$ \\
\hline electoral system & - serves the parties not the citizens \\
\hline $\begin{array}{l}\text { functioning of the } \\
\text { state }\end{array}$ & $\begin{array}{l}\text { - the state is a repressive institution for citizens, not one serving them } \\
\text { - unfavourable taxation system for citizens } \\
\text { - provileges for huge corporations transfering profits abroad at the costs of small } \\
\text { and medium business }\end{array}$ \\
\hline $\begin{array}{l}\text { legeslative and } \\
\text { administration }\end{array}$ & $\begin{array}{l}\text { - ailing legislative process and axcessive bureaucracy } \\
\text { - corruptions and nepotism }\end{array}$ \\
\hline $\begin{array}{l}\text { court system and } \\
\text { police }\end{array}$ & $\begin{array}{l}\text { - lengthiness of court casses, inappriopriate practical prepartaion of judges } \\
\text { - police does not serve the citizens but the state authorities }\end{array}$ \\
\hline $\begin{array}{l}\text { relations between } \\
\text { state and church }\end{array}$ & - privileged position of the Catholic Church in public life (Your Move(ment) only) \\
\hline
\end{tabular}

Source: developed by the authors based on party programmes 


\subsection{The propositions for change}

The criticism presented above of the existing regime and establishment parties as reflected in the programmes of the two parties herein under analysis is supplemented by their proposals for reforms which are to cure the situation. The cure-all for the omnipresent particracy is to be a change in the way parliamentary deputies are elected as well as the way in which political parties are financed. The Palikot Movement proposed in their 2011 election programme a mixed electoral law, whereby political parties would influence only a half of the seats in parliament. The original proposal was also to introduce a limit on the number of parliamentary terms as well as connecting the number of deputies voted in with the electoral turnout, whereby regions where the turnout was higher would have more deputies to represent them in parliament. Actual change within the electoral law is, however, not particularly highlighted within the Your Move(ment) programmes, and that being in stark contrast to the Kukiz'15 association, which made it the axis of its 2015 election appeal to voters. Election law reform is to involve the creation of individual election constituencies which - as may be read in the programme - "[...] are a guarantee for an ethical renewal and a return to standards within Polish politics" (Kukiz, 2015, p. 7). On the matter of party financing, Kukiz'15 - not being a party in the formal sense - advocates the ending of state funding for political activities, claiming that "honest politics is politics financed by citizens" (Kukiz, 2015, p. 13). In turn, the Palikot Move(ment) proposes a change in the form of financing whereby citizens themselves decide which party they want to support. This was to take the form of deeds of covenant for party needs taken out as part of the annual income tax declaration $(R P-$ 2011,2013 , p. 334). An important proposal to curb the power of party leaders and the forcing of a generational change is the proposal to limit the number of terms of office that may be served to a maximum of two ( $R P-2011,2013$, p. 334).

Proposals for changes in state structures are put forward as ways in which the functioning of the Polish state could be improved. Your Move(ment) proposes the eradication of the second chamber of the Polish parliament, the Senate, whose existence unnecessarily extends the legislative process while not resulting in any qualitative improvement for any law in question (RP/TR, 2011). Another proposal involves the introduction of a limit of two terms of office for all representatives selected by means of public election: parliamentary deputies, local government councillors, mayors and other elected urban leaders (RP/TR, 2011). In turn, Kukiz'15 has proposed the transformation of the political order into 
a state based on presidential system, where the president elected in the general election was to hold "total executive power" (Kukiz, 2015, p. 7). The president was to stand at the head of government, without the right to legislative initiative, which should lie with parliamentary deputies and ordinary citizens.

An important element of constitutional reform allowing for greater citizen control over the functioning on state institutions was to be the increase in the importance of direct democracy. Your Move(ment) proposes the strengthening of citizen influence on the functioning of the state through local and national referendums as well as social consultation at both local and national levels, including a participatory budget. The development of information technology is to serve to create free public debate, not monitored by the media. While in Kukiz'15's programme we find the idea of introducing an obligatory referendum, the validity of which would not be determined by election thresholds. Once a year there should be a "referendum day", on which all problems and issues would be voted on that had been proposed and submitted by a minimum of half a million citizens (Kukiz, 2015, p. 7).

The cure-all for the lack of transparency in matters of public expenditure would be - according to Your Move(ment) - placing the relevant information on the Internet and presenting it in a way accessible to the average citizen. The 2011 election programme announced a reduction in the national budget deficit by a half in the course of two years through reducing spending on the armed forces, the Catholic Church, and political parties. Tax reform should involve the very same rate, $18 \%$, for all the CIT, PIT and VAT types of taxation, which would make Poland more competitive with those countries where linear tax applies ( $R P-2011,2013$, pp. 340-341). Your Move(ment) also proposes that foreign investors who have made use of tax incentives and benefits should be subject to an "exit tax" if they were to decide to suspend operations in Poland (RP/TR, 2011). In addition, proposed was an easing in the procedure for setting up new enterprises ("a company on a trial period" programme), advanced were proposals for changes in the act on public services contracts whereby price valuation alone would not to be the only deciding factor (TR, 2014).

According to the Kukiz'15 association, a broadening of the right to access to public information would aid the transparency and control of public spending (Kukiz, 2015, p. 11). Excessive state debt should be countered by the inclusion in the Constitution of the need to pass balanced fiscal budgets, both at central and local government level (Kukiz, 2015, p. 16). Tax reform should, in turn, lead to a greater level of taxation on large and foreign enterprises, including 
banks and an easing in proceedings for Polish investors. An important aspect of the programme is the increase in the tax-free allowance for PIT taxation over transitional period, with the eventual abolishment of this tax, as well as to initiate reforms of VAT and CIT (Kukiz, 2015, p. 21). The defence of Polish interests internationally was to involve, among other things, concerted action to limit the intervention of EU institutions in the functioning of sovereign member states. A most clear declaration on terminating the EU's climate package was also made (Kukiz, 2015, p. 30).

Both groupings also advance interesting proposals for increasing the effectiveness of state institutions, including reform of the judiciary. Your Move(ment) wishes for changes in the career path for judges so that the position of judge would not be held by someone only at the beginning of their legal career and consequently by someone of limited and therein insufficient life experience, but would be held by individuals who had already worked in other legal fields, with becoming a judge representing the pinnacle of one's legal career. Also postulated is the inclusion within sentence passing procedure of judges elected by citizens in general elections as well as a speeding up of court procedures whereby processes are dealt with on a day-by-day basis (TR, 2014). Similar proposals are presented by the Kukiz' 15 association, which equally wants the position of judge to constitute the crowning of a legal career, with cases being dealt with on a continuous basis. However, a fundamental change would see judges chosen by citizens as well as the introduction of an institution termed "a judge of the peace" (JP), one who would be universally elected and would deal with offences as well as "minor neighbourhood civil matters" (Kukiz, 2015, p. 9). The Your Move(ment) programme proposes the monitoring and evaluation of the work of the police, who should concentrate on arresting serious criminals and not lying in wait to catch ordinary citizens for minor offences. Kukiz'15 places greater score on the armed forces and postulates, among other things, the creation of a "citizen component" for the armed forces in the form of a territorial defence unit (Kukiz, 2015, p. 25).

Your Move(ment) and Kukiz'15 also want to counter excessive bureaucracy. The wish of Your Move(ment) is for the revitalisation of state administration through the introduction of "principles of silent agreement" as well as of "declarations in place of certificates" $(R P-2011,2013$, p. 337). The former means that if a government office does not issue a decision within the timeframe given then any decision taken will be beneficial to the applicant. The latter requires government offices not to demand certificates from other government departments, 
these should be replaced by citizens' own statements relating their marital status, no criminal record, etc. This would reduce administration costs while at the same time increase the mutual sense of trust and responsibility for citizens. Your Move(ment)'s programme also envisages responsible conduct on the part of government employees for decisions wrongly taken, with fines for any delay in their realisation. Kukiz'15 similarly proposes the eradication of various administrative requirements: licences, permissions and limitations in economic activity as part of the fight against excessive bureaucracy (Kukiz, 2015, p. 22).

Your Move(ment) places great importance on the need for reform in ChurchState relations, which are to annul the financial privileges enjoyed by the former as well as to lead to the termination of the concordat (RP/TR, 2011). It demands the total neutrality of state authorities in matters of religious convictions and views. As a result they propose: liberalisation of the law on abortion, statesponsored financing of in vitro fertility methods, free access to contraceptives, as well as the legalisation of heterosexual and homosexual civil unions together with a legalisation of soft drugs. The party also places great emphasis on equal rights for women and men in all spheres of life ( $R P-2011,2013$, pp. 335-336).

\section{LET US START WITH OURSELVES, THAT IS, NEW SOLUTIONS WITHIN ENTREPRENEURIAL PARTY STRUCTURES}

The parties herein discussed went into the elections with programmes proclaiming that they wanted to implement political change in Poland. In criticising the existing establishment parties they presented themselves as an alternative to them, "a movement of people that wish to regain their country" ( $R P-2011$, 2013 , p. 337) or a formation whose aim was "the return of control to the citizens over the state itself" (Kukiz, 2015). This appears to enter well into contemporary trends advocating increased internal party democracy, a strengthening of the role played by party members and the involvement in party activities of individuals from outside of the party (Scarrow, 2015). Political parties operating within stabilised western democracies increasingly introduce to their structures solutions that involve: the election of the leader on the basis of a OMOV rule, sometimes including also party sympathisers; the introduction of primaries as a means to select candidates for election to public bodies, the involvement of members and sympathisers in discussions over programmes, and here increasingly utilised are Internet platforms. It is therefore worth recalling in this context that both 
of the formations discussed here included in their programmes the demand for increased use of referendums. Your Move(ment) equally drew attention to the need for large scale social consultation as well as the possibility for citizens to engage in political debate by means of the Internet. The Kukiz'15 association also made direct recourse to democracy in its statute, declaring the desire to guarantee the precedence of referendum over other forms of public authority decisions, as well as the promoting and support of popular initiative and the propagation of the idea of a civil society (Kukiz, 2015).

In accordance with the idea of introducing changes starting from oneself, the question to be analysed was whether the said entrepreneurial parties implemented into their structures and activities the solutions postulated in their programmes. And in this way the party statutes and means by which election lists were drawn up for the Sejm parliamentary election were analysed. In the case of Kukiz'15 the association's statute: Statut Stowarzyszenia na rzecz Nowej Konstytucji Kukiz'15 (Statut Kukiz, 2015) was taken into consideration, while for Your Move(ment) three statute documents were examined: the statute adopted at the moment the party was formed in 2011 (Statut RP, 2011), the document sanctioned when the party's name was changed in 2013 (Statut TR, 2013), as well as the present statute in force since 2015 (Statut TR, 2015). The mentioned documents are fairly similar though certain corrections may be observed in them which are significant with regard to the solutions implemented.

Research has shown that contrary to what had been said these entrepreneurial parties did not implement any form of direct democracy whatsoever to their organisational structures, in the form of: internal party referendums, primary elections, or consulting with the membership. In the statute of the Palikot Movement/Your Move(ment) envisaged had been the possibility of only the National Political Council taking resolutions on membership consultation. In the first two versions of the statute noted was also the possibility for the District Board - in consultation with the National Board - to allow for primary elections. In the 2015 version of the statute this regulation has been removed (Statut TR, 2015). In the statute regulations of Kukiz'15, there are also no formulations allowing for any individuals outside of its ranks to join in the decision-making process, for example, those classified as sympathisers. This was also not envisaged in the first statute of the Palikot Movement, with it being introduced only following the change in party name and statute in 2013. There, however, the position and role of sympathisers was not precisely defined, recourse being made in this matter to the resolution of the National Board. 
The organisational structures of both formations are based first and foremost on the traditional models adopted for representative democracy, though in those organs at the lower levels there is the possibility for the participation of all the members from a given area. The leaders are selected by the central resolutionmaking organs, in the case of Kukiz'15 this is the National Assembly of Delegates, while in the Palikot Movement - the National Congress. A certain novelty in Your Move(ment) - introduced into the statute in 2015 - is the election of two leaders of the Movement which - in connection with the principle of parity for men and women within the Movement's organs at all levels - means that one of the two joint leaders has to be a woman. The above solution is clearly the result of the realisation of the programme adopted by Your Move(ment) in which men and women are seen as being equal in all spheres of life. Additionally, in each of the three statute versions can be found a regulation stating that the same person may perform the same function for a maximum of two terms of office, which equally may be seen as the realisation of one of the proposals from the party's programme. In Kukiz'15, the leader has been, since the moment the association was formed, Paweł Kukiz, and in Your Move(ment) - Janusz Palikot. Following the introduction of two leaders in 2015 the co-leader was Barbara Nowacka.

The formations, in proclaiming a new quality in politics and through criticising the existing parties, have not made recourse to new methods of activity that involve the inclusion of ordinary citizens but rather have adopted organisational solutions that recall in their form those used by traditional parties. The only area which displays any innovations is the way in which the election list was drawn up. As entrepreneurial parties, both groupings started their activities without any support from social movement or sponsor organisations (Hloušek \& Kopeček, 2017), at the moment of election commencement they equally did not have a grassroots party structure, consequently they had to be open to individuals who were not their members. Both groupings - the Palikot Movement in 2011, and Kukiz'15 in 2015 - recruited candidates through Internet sites (Kosowska-Gąstoł \& Sobolewska-Myślik, 2017, pp. 141, 147). In the Kukiz'15 Statute the matter of creating an election list of candidates takes up very little space, though one needs to remember that formally this is not a political party, and therefore activity of this type may be treated far less rigorously than in the case of an actual political party. In Your Move(ment), various organs are involved in the creation of the election list - the regulations and principles under which it is drawn up are determined by the National Policy Council, its compilation is the job of the District Board, opinionated to the District Policy Council, while the final say 
belongs to the National Board (Statut TR, 2015). A significant novelty is the regulation contained in the statute on the alternation of sex in the creation of election candidate lists. This was adopted in the election of 2011. Though one can observe a certain inconsistency. In certain districts the lists contained the alternation of men and women, while in others - two men then two women. In addition, for 41 election districts, women only found themselves in first place four times (Kandydaci RP - 2011, 2013,2011).

\section{LET US CHANGE POLITICS, OR THE PROPOSALS OF ENTREPRENEURIAL PARTIES WITHIN PARLIAMENTARY PRACTICE}

The parties herein under consideration took no part in governing for they merely managed to pass the electoral threshold needed to enter parliament and for their representatives to take their seats in the Polish Sejm. Thus they gave themselves a platform to promote their ideas within the parliamentary arena and to implement with the same their "modern change" as proclaimed in their political programmes. The analysis conducted of the parliamentary addresses and debate contributions made by the deputies of both groupings as well as a review of the legislative initiatives advanced by them enables us to evaluate whether they took advantage of the opportunity given them by voters and if they did attempt to put into practice their political programmes. It is worth, given this context, to draw attention to how deputies of Your Move(ment) as often criticised in their addresses existing institutions and activities as they presented their own proposals for their rectification; while the representatives of Kukiz'15 restricted themselves chiefly to criticism itself. Consequently, any proposals for changes advanced by the association can be found mainly in the legislative initiatives proposed by its parliamentary group.

The parliamentary speeches of MPs from both formations abound with criticism of political and party elites. According to a representative of Your Move(ment), "it would follow to call for a vote of no confidence in the entire Polish political class", while Kukiz'15 emphasises that: "For years the Polish parliament has involved itself in internal fighting, not troubling itself with matters important for the ordinary citizen". A point of reference is equally not limiting political rivalry on the Polish scene to the struggle between PiS and PO, which was to find reflection in an utterance by a Kukiz'15 deputy: "I most kindly ask that the right to stand for election be not taken away from citizens when the 
matter concerns local government, and make the appeal [...] that you do not create a two-party system in Poland, that is, a formal division between PO and PiS". These parties criticise the domination of political life by the establishment parties. A deputy from the Your Move(ment) asked: "Prime Minister, [...] will you put an end to the practice where party affiliation is a prerequisite to the obtainment of positions?". This view was echoed by a Kukiz' 15 deputy who said: "[...] this is life in a state subordinated to a single party, etatism and centralism. I am not prepared to accept a Poland of such a hue". Equally pointed out was that party domination results in abuse and corruption, as is borne out by the following remarks of a Kukiz'15 deputy: "Give back the money which you have earmarked for 10,000-złoty suits, for octopuses, and various party dos", "to me it appears to be some little act with the bailiffs of all the parliamentary clubs. [...] I hasten to emphasise «of all»".

It results from what has been said by the Kukiz'15 deputies, that the source of the negative phenomena connected with party functioning lies in a voting system that results in parties being shut off from contact with ordinary citizens: "If all of you had been elected in single election districts then you would go about this act quite differently". In turn, Palikot Move(ment) deputies are rather inclined to blame the way that parties are financed for the existence of party bipolarity along with all the manifestations of political ills, which they describe as "a bank job in the light of the law", hence the large number of comments criticising this state of affairs and the introduction of new solutions to rectify this pathological state of affairs. Attention is drawn that "the Polish state has started to transfer funds for the activities of selected political parties with no recourse to the principle of freedom of choice. [...] The taking of such a decision is one of the most important in cementing the Polish political scene". While the reform proposed is to involve "the voter obtaining an instrument that allows him to evaluate political groupings annually".

The parliamentary criticism emanating from both groupings was also directed against the poor functioning of the state and its institutions. A Your Move(ment) deputy has encapsulated the said as follows: "If that is what a modern state friendly to its citizens is to look like, that on $\mathrm{x}$-number of pages a verification system is elaborated, a system of control, and then as if this is not enough more pages are incorporated as sanctions, ones that threaten, then in my opinion this act is not worthy of support". In turn, a representative of Kukiz'15 noted that "we are indeed merely a fictitious state, one existing in theory only". The Palikot Movement proposed a series of issues that were to change this, e.g., the limitation 
of parliamentary terms for deputies, the dissolving of the Senat (the Polish upper house of parliament) and restrictions on the number of terms that city mayors can be in office.

The judiciary come in for especial criticism by both parties. This finds expression in the wording of one Kukiz'15 parliamentarian: “[...] if the state [...] becomes the main enemy of the people, then where are these people to go? To the courts? They can go to court but I don't know whether you know that a case in court lasts $2-3$ years and costs on average 15 to 20,000 złoty, while families are struggling for enough money for bread and a bus ticket, struggling just to survive". According to a Your Move(ment) deputy: "Today a civil servant is still able to do with a citizen whatever he likes and then this citizen can go to court and try to prove his innocence for years. While at court it's all on the toss of a coin: either the judge shows interest or he doesn't, anyway there will always be a problem". The said party advocated reform of the judiciary: "Our main goal is to introduce the judicial factor into preparatory proceedings and to end a certain fictitious state that exists. [...] We equally want these changes to result in a speeding up of proceedings. If we are to talk of costs then we should equally remember that the Polish state will incur these and does incur the costs of drawn-out proceedings. And it is for us to answer the question as to whether we want to continue to live in such a state".

Both parties have often criticised the poor functioning of the legislative process, hastily conducted, without due diligence, resulting in the passing of laws that first and foremost support political interests. This is borne out by the words of a Palikot Movement deputy: "[...] Why does the legislative chamber produce, draw up, and pass acts of such poor quality, in a word, legal pieces of trash", "in the name of what are we to once again rescue a flawed law and correct the mistakes of our predecessors or our very own? I think that we should think long and hard over any new acts, so that such situations do not occur for this really is an enormous waste of our time". As well as statements made by the Kukiz'15 association: "Gentlemen, out of slovenliness you forgot about normal legislation", "Why do we allow ourselves to continue in such an agitated manner, not thought-through? Then legal acts have to be rectified, ones only recently passed, so that they don't actually cause harm to concrete individuals. Given this state of affairs, I would propose we remember this and that in future we concentrate on the quality of law, and not on its politicization". The Kukiz' 15 association also criticised the lack of social consultation in the process of law creation: "There is, unfortunately, no consultation as this is the proposal of parliamentary deputies, 
and not governmental, there is no need to present the effect of an act and - summing up - there is an absence of depoliticization".

Deputies from both formations have devoted a lot of room in their addresses to a criticism of bureaucracy and nepotism. The first was to become particularly the domain of the Palikot Movement, which not only criticised the poor functioning of bureaucratic structures, but also proposed changes: "[...] the most important thing is to arrive at administrative responsibility. If a government employee is responsible for [...] what they say then this means that they will surely try to get the applicant to come to them and that they are there for the applicant and not the other way around, the applicant for the bureaucrat". Proposed in Sejm addresses was the Palikot Movement initiative that in place of submitting for government offices of certificates issued by other government departments there should be introduced citizen declarations (statements) which would not only result in a decrease in bureaucracy but would also "be a breakthrough by being a hitherto untried practice in building faith in the honesty of Poles".

One may find examples in the statements of deputies from both parties of nepotism, something the largest political parties in Poland are accused of. A Your Move(ment) deputy pointed out that: "The only thing proved [...] was that the buying of positions, jobs on the side, lucrative contracts is for many members of the Civic Platform their daily bread". In turn Kukiz'15 raised the questions: "And maybe those district councils that were [...] simply the price one had to pay Chairman [...] in exchange for the family sinecure of one of the Law and Justice party's ministers in municipal firms?" According to the Palikot Movement, the cure-all for corruption at the local level could be the limiting of the terms of office that mayors and city presidents can serve to two periods in office which would "make it difficult for the creation and functioning of corrupt cliques within local circles. [...] We know this from life itself - there are 30 candidates and one of them has long ago already been selected".

An extremely important issue, one often raised in addresses made by representatives of the Palikot Movement, is the question of the separation of the Catholic Church from the Polish state: "We shall finally bring to an end the diktat of the Catholic Church in Poland". Many times Palikot deputies demanded the ending of financial breaks for the Catholic Church: "is the government for the eradication of the Catholic Church Fund [...] if its removal is to mean that for subsequent years we are going to an even greater degree finance the Catholic Church than has hitherto been the case, then please explain this to the entire 
Polish nation", as well as the dropping of religion as a subject at school and the removal of religious symbols from public institutions. They also raised social issues like the legalisation of civil unions: "civil unions were, are, and will be. It is our role, the role of the authorities, to merely provide them with protection, to give them freedom and to ensure equality, equality in the face of the law", the legalisation of abortion and the financing by the state of in vitro methods of fertility treatment: "Prime Minister, will we finally be told whether the government intends to pass a bill on in vitro or not?". They also devoted a lot of time to the question of equal rights for men and women: "equal rights, equal laws, a half of government, as well as the very same pay".

The deputies of Your Move(ment) and Kukiz'15, besides presenting in the parliamentary addresses their critical stance towards the existing elites and political institutions, also attempted to impact on the state's agenda through the introduction of legislative initiatives. Their draft bill proposals were often rejected at the introductory stage of legislative work or even before this was commenced. This was noted by one of the deputies addressing parliament: "Honourable members of the house, it is most sad for me to learn that this package of bills was condemned to failure and rejection on the part of the governing coalition simply because it had been tabled by the Palikot Movement". A similar fate was to befall those bills tabled by Kukiz' 15 deputies. This explains the small number of bills which were passed at the initiative of deputies from both parliamentary groups. Amongst the legislative successes of Your Move(ment) are, first and foremost: the amendment to the Code of Criminal Proceedings involving the introduction of the institution of a judge to preparatory proceedings as well as amendments to the act on public tenders and bidding, to which was included the criterion of innovativeness. The main success of Kukiz' 15 was a change to the act on local government employees which involved the eradication of so-called "political cabinets" functioning at the level of local government, that is, de facto posts of advisers and assistants of municipal and provincial officers such as town mayors or city presidents.

In the case of Your Move(ment), it is worth drawing attention to the fact that certain legislative concepts that were rejected by parliament were subsequently to be made use of by the government and incorporated into their own projects (the amount exempt from tax, the payment of VAT only after the recipient has paid the invoice). However, the flagship proposals promoted by Your Move(ment) were never to see realisation: these concerning changes to the code for administrative procedure involving fines for administrative organs failing to meet deadlines, as 
well as a simplification of the documentation requirements (declarations replacing certifications). There was equally no implementation of changes to the act on the financing of political parties. The project for change in party financing that was tabled by Kukiz'15, and which envisaged the eradication of budget subventions, equally never saw realisation. Other projects tabled by Kukiz'15, and which may be considered key, concerned single-member electoral districts for local government elections; changes to make local referendums easier to conduct including the removal of a participation threshold for referendum validity, as well as the introduction of an obligatory public registration of orders placed by units from publically financed sectors.

The question of amendments to the electoral code with the aim of reducing the terms of office that could be held by the heads of local government elected tiers including the position of mayor, one important to both parties, was to finally be passed by the Sejm in January 2018 when there were no longer any representatives of Your Move(ment) elected to parliament. In addition, this change was incorporated within a broader packet of reforms on the way local government organs were to function, as well as changes to the election law and consequently the act was not supported in the parliamentary vote by Kukiz'15 deputies. Another group of the Your Move(ment)'s legislative proposals that was to end up forgotten concerned civil unions, easing the procedures for sole-trader registration (first and foremost "a company on a trial period"), or the eradication of the Church Fund. Kukiz'15 still has a parliamentary representation and consequently still has an opportunity to promote its political proposals.

\section{CONCLUSIONS: MUCH ADO ABOUT NOTHING}

Polish entrepreneurial parties, despite taking a concrete position in relation to the policies of subsequent governments as well as relations between citizens and the state, are not viewed as factors that can change Polish politics. In this point, it is worth returning to the question posed in the title as to whether entrepreneurial parties make any difference for politics in Poland. The Palikot Movement and Kukiz'15 entered into it by having convinced the electorate that they differed from traditional political parties and that their desire was to create a new quality within Polish politics. However, in all elements analysed in the article: party statutes and programmes, parliamentary speeches and legislative initiatives, we did not find any issues that bear potential for significant change. 
Both formations drew attention to similar maladies in Polish politics. Their programmes contained much criticism of existing political elites and establishment parties as well as criticism of the weak nature of the Polish state and the lack of trust it generated in the public at large. Both parties saw the poor working of the judiciary, the ineffective legislative process, excessive bureaucracy, as well as corruption and nepotism to be amongst the greatest of the ills threatening Poland. In criticising the faulty workings of certain institutions of the Polish state, these entrepreneurial parties did not intend to bring about their deconstruction, but merely to implement certain innovations and improvements. Both formations proposed a series of reforms that were to rectify the situation. Among those propositions one can find a few issues which could be seen as specific for the discussed parties and in the same time could be interpreted as their ideas to change the quality of Polish politics. In case of Kukiz'15, it was the proposition of the reform of the electoral system, aiming at creation of the single member districts. In case of Your Move(ment), it was the question of change in the privileged position of the Catholic Church in Poland.

Both groupings fared no better in promoting their ideas within the parliamentary forum, although certain differences may be perceived between them. As far as Kukiz'15 deputies concentrate in their addresses on criticism of the existing regime, those from Your Move(ment) often connected this with the presentation of their own proposals for change. Both formations utilised the right for deputies to initiate legislative motions attempting in this way to implement the changes they proposed. However, their initiatives did not meet with the approval of the parliamentary majority, and consequently they did not manage to impact on Polish reality. As far as organizational structures are concerned, both formations duplicated in their statutes the solutions characteristic for traditional political parties, they did not implement any forms of direct or deliberative democracy, and consequently here one cannot speak of the invoking of any new quality whatsoever. An exception is, however, within the structures of Your Move(ment) where the parity principle for sex found its reflection in both the drawing up of election candidate lists as well as in the personal appointments for all party structures including the two-person leadership.

In effect, it follows to state that despite the faith shown them by the electorate they equally were unable to instigate any of the significant changes they had proclaimed in their political appeals. 


\section{REFERENCES:}

Biezen van, I., Mair, P., \& Poguntke, T. (2012). Going, Going,... Gone? The Decline of Party Membership in Contemporary Europe. European Journal of Political Research, 51(1), 24-56. DOI: 10.1111/j.1475-6765.2011.01995.x.

Deegan-Krause, K., \& Haughton, T. (2015). Hurricane Season: Systems of Instability in Central and East European Party Politics. East European Politics and Societies and Cultures, 29(1), 61-80. DOI: 10.1177/0888325414566072.

Della Porta, D., Fernández, J., Kouki, H., \& Mosca, L. (2017). Movement Parties Against Austerity. Malden: Polity Press.

Enyedi, Z. (2014). The Discreet Charm of Political Parties. Party Politics, 20(2), 194-204. DOI: $10.1177 / 1354068813519959$.

Hartleb, F. (2015). Here to Stay: Anti-Establishment Parties in Europe. European View, 14(1), 39-49. DOI: 10.1007/s12290-015-0348-4.

Hloušek, V., \& Kopeček, L. (2017). Entrepreneurial Parties: A Basic Conceptual Framework. Czech Journal of Political Science, 24(2), 83-91. DOI: 10.5817/PC2017-2-83.

Hopkin, J., \& Paolucci, C. (1999). The Business Firm Model of Party Organisation: Cases from Spain and Italy. European Journal of Political Research, 35(3), 307-339. DOI: 10.1023/A:1006903925012.

Kandydaci RP - 2011 (2013). Kandydaci Ruchu Palikota w okręgach wyborczych. In: I. Słodkowska, \& M. Dołbakowska (eds.). Wybory 2011. Partie i ich programy (pp. 313-332). Warszawa: Instytut Studiów Politycznych Polskiej Akademii Nauk.

Katz, R.S., \& Mair, P. (1995). Changing Models of Party Organization and Party Democracy: The Emergence of the Cartel Party. Party Politics, 1(1), 5-28. DOI: https://doi. org/10.1177/1354068895001001001.

Kessel van, S. (2015). Populist Parties in Europe. Agents of Discontent? Basingstoke: Palgrave Macmillan UK. Kosowska-Gąstoł, B. (2018). Od sukcesu do porażki - Twój Ruch w świetle wybranych modeli partii. In: A. Pacześniak (ed.). Anatomia porażki wyborczej (pp. 128-148). Warszawa: Wydawnictwo Sejmowe.

Kosowska-Gąstoł, B., \& Sobolewska-Myślik, K. (2017). New Political Entrepreneurs in Poland. Czech Journal of Political Science, 24(2), 137-157. DOI: 10.5817/PC20172-137.

Krouwel, A. (2006). Party Models. In: R. Katz, \& W. Crotty (eds.). Handbook of Party Politics (pp. 249-269). London: Sage.

Kukiz (2015). Strategia zmiany. Potrafisz Polsko. Kukiz'15. Retrieved from: http:// ruchkukiza.pl/klub-poselski/strategia-zmiany/.

Lucardie, P. (2000). Prophets, Purifiers and Prolocutors. Towards a Theory of the Emergence of New Parties. Party Politics, 6(2), 175-185. DOI: 10.1177/1 354068800006002003.

Markowski, R. (2006). The Polish Elections of 2005: Pure Chaos or a Restructuring of the Party System? West European Politics, 29(4), 814-832. DOI: $10.1080 / 01402380600842452$. 
Markowski, R. (2008). The 2007 Polish Parliamentary Election: Some Structuring, Still a Lot of Chaos. West European Politics, 31(5), 1055-1068. DOI: $10.1080 / 01402380802234763$.

Natale, S., \& Ballatore, A. (2014). The Web Will Kill Them All: New Media, Digital Utopia, and Political Struggle in the Italian 5-Star Movement. Media, Culture and Society, 36(1), 105-121. DOI: 10.1177/0163443713511902.

Państwowa Komisja Wyborcza (2019). Retrieved from: www.pkw.pl.

Research Randomizer (2019). Retrieved from: www.randomizer.org.

RP - 2011 (2013). Program wyborczy. Nowoczesna Polska, election brochure of the Palikot Movement. In: I. Słodkowska, \& M. Dołbakowska (eds.). Wybory 2011. Partie $i$ ich programy (pp. 332-342). Warszawa: Instytut Studiów Politycznych Polskiej Akademii Nauk.

RP/TR (2011). Program „Nowoczesne Państwo. Świeckie państwo. Państwo przyjazne”. Retrieved from: http://twojruch.eu/nowoczesne-panstwo.

Scarrow, S.E. (2015). Beyond Party Members. Changing Approaches to Partisan Mobilization. Oxford: Oxford University Press.

Stanley, B., \& Cześnik, M. (2016). Poland's Palikot Movement: Voice of the Disenchanted, Missing Ideological Link or More of the Same? Party Politics, 22(6), 705-718. DOI: $10.1177 / 1354068814560911$.

Statut Kukiz (2015). Statut „Stowarzyszenia na Rzecz Nowej Konstytucji Kukiz'15”. Retrieved from: http://kukiz15.org/images/DOLACZ/Statut-Stowarzyszenia-narzecz-nowej-Konstytucji-KUKIZ15.pdf.

Statut RP (2011). Statut Ruchu Palikota. Warszawa: Ruch Palikota. Retrieved from: http://web.archive.org/web/20130309101205/http://www.ruchpalikota.org.pl/sites/ default/files/plikownia/ruch_pl_statut.pdf.

Statut TR (2013). Statut Twojego Ruchu przyjęty na III Kongresie Krajowym Ruchu w dniu 5 października 2013 roku. Warszawa: Ruch Palikota (in the authors' collection).

Statut TR (2015). Statut Twojego Ruchu przyjęty przez Kongres Krajowy w dniu 20 czerwca 2015 roku. Retrieved from: http://twojruch.eu/dokumenty/.

Szczerbiak, A. (2013). Poland (Mainly) Chooses Stability and Continuity: The October 2011 Polish Parliamentary Election. Perspectives on European Politics and Society, 14(4), 480-504. DOI: 10.1080/15705854.2013.793535.

The Sejm (2019). Retrieved from: www.sejm.gov.pl.

TR (2014). Program. Plan zmian 2014-2019. Retrieved from: http://twojruch.eu/ dokumenty/.

Whiteley, P.F. (2011). Is the Party Over? The Decline of Party Activism and Membership Across the Democratic World. Party Politics, 17(1), 21-44. DOI: 10.1177/1354068810365505. 